\title{
Methods of Family Planning Used Over a Period of One And A Half Years in Olorunda Local Government Area of Osun State, Nigeria
}

\author{
Falode, D.T.; Akintaro, O.A. \\ Department of Community Health, Obafemi Awolowo University, Ile-Ife. \\ Department of Human Kinetics and Health Education, University of Ibadan, Ibadan.
}

\begin{abstract}
This study is a retrospective one covering a period of one and a half years (October 2005-April 2007). The research was carried out in four maternity centers, namely, Akogun, Oke-Onitea, Ota-Efun, and Atelewo, all in Olorunda Local Government Area of Osun State, Nigeria. According to the 2006 population censures, the population of Olorunda Local Government Area is 126, 374. The male and female population is $49.4 \%$ and $50.6 \%$ respectively. Total sampling technique was used to select the respondents for this study. All available records of 494 clients who attended the clinic between October 2005 and April 2007 were studied. Descriptive statistics of frequency counts and percentages were used to analyze the data of the respondents. The result showed that the number of new cases was slightly more than revisits and other cases. It was therefore recommended that the ongoing efforts aimed at educating the people about the benefits of family planning should be sustained.
\end{abstract}

Key Words: Family planning, population, pregnancy, abortion.

\section{Introduction}

Family planning is a concept or process that deals with child birth control using contraception. It entails decisions made by women and men concerning their reproductive health, choices in the timing, spaces and in what circumstances they have their families. It is a way of thinking and living that is voluntarily adopted on the basis of knowledge, attitudes, and responsible decision by individuals and couples so as to promote health and wellness of the family group thereby contributing effectively to the socio-economic development of the country. In a nutshell, family planning is the willful control of fertility. Family planning is one of the most basic and essential health-care services. The ability to choose the number and spacing of their children promotes healthier mothers and children, as well as smaller families that are better able to meet their household's economic needs. At least, 200-million women-in-need lack access to modern methods of family planning (United Nations Millennium Project, 2006).

According to Almuam (2007), family planning is defined as birth spacing, preventing unwanted pregnancies or secures wanted pregnancies. Family planning is adopted voluntarily through the practice of contraception or other methods of birth control on the basis of knowledge, attitude and responsible decision by individuals and couples, in order to promote the health and welfare of the family thereby contributing to the social and economic development of the country. Family planning has been identified by the World Health Organisation (WHO) as one of the six essential health interventions needed to achieve safe motherhood and by United Nations Children Fund (UNICEF) as one of seven strategies for child survival. Both women and men's use of contraception has been going on for centuries. Traditional methods such as coitus interruptus is described in the Bible, periodic abstinence was used in ancient India and the precursor to the condom was used by the Egyptians back in $1350 \mathrm{BC}$.

Visaria (2000) stated that family planning programme has evolved through a number of stages, and has changed direction, emphasis and strategies; during the first decade of its existence, family planning was considered as a mechanism aimed at improving the health of mothers and children than a method of population control. Family planning is an important aspect of women's health and lives. Childbearing intervals, number of children and choice of contraceptive method impact on women's gynecological and overall health, as well as their social and economic status in society. Frequent childbearing, short birth intervals, and unsafe abortion contribute to maternal mortality and morbidity in the developing world. In Africa, a good number of all pregnancies are unintended, significantly impacting on women's physical, social and economic well-being.

Sedgh, Henshaw, Singh, Ahman and Shah (2007) submitted that the combination of an increase in population and low contraceptive use has increased the annual number of unintended pregnancies to 80 million in the developing countries. Family planning is an effective means of reducing maternal mortality by preventing unwanted pregnancies and unsafe abortions and by promoting healthy pregnancies, that is, maternal age and parity, and birth spacing (Marston \& Cleveland, 2004). 
The primary aim of family planning is to enable women and men to plan their families and space their children through the use of modern contraceptives. However, family planning also embraces activities such as infertility and genetic counseling, contraception, abortion and sterilization. Family planning programs, policies and methods have become increasingly important in the last decade as a result of the socio-economic problems influencing rapid population growth, as well as public health problems, especially control of sexually transmitted diseases (STDs) such as AIDS (United Nations, 1995).

Carl and Mary (2008) hinted that family planning could prevent as many as one in every three maternal deaths by allowing women to delay motherhood, space birth, avoid unintended pregnancies and abortion and stop childbearing when they reached their desired family size. Estimates show that about 6.7 million induced abortions take place annually in India (National Commission on Population, 2002). Several studies report that the desire to limit family size and to space the next birth are the main reasons for abortion mentioned by the majority of abortion seekers (Ganatra, 2000).

According to Olugbenga-Bello, Abodunrin and Adeomi (2011), virtually all married women in industrialized countries resort to contraception at some time in their reproductive period, whereas, the proportion reporting such in developing countries is extremely low. Khurfeld (2006) opined that Nigeria is already facing a population explosion with the resultant effect that food production cannot match the growing population. Studies have reported low adoption rate of Modern Birth Control Methods (MBCM) (Population Reference Bureau, 2002; UNFPA, 2007).

Despite important gains, progress in achieving good reproductive health is very unevenly distributed. Poor women and men are the most in need and the least well served. Early and unwanted childbearing, pregnancy-related illnesses and deaths account for a significant proportion of the burden of illness experienced by women, especially women in low-income countries (United Nations, 1995). Every year, 250 million years of productive life are lost due to death or disability related to poor sexual and reproductive health (United Nations Population Fund, 2005). Based on the aforementioned, the researchers investigated methods of family planning used in Olorunda Local Government Area of Osun State, Nigeria over a period of one and a half years.

\section{Statement of the Problem}

According to Osemwenkha (2004), it is estimated that half of all births in many less developed countries, including Nigeria pose high risks to the health of both mother and child, as births occur to women who are too old or too young, or who have many previous births, or whose current births are too close to the previous birth. In Nigeria today, the birth rate is higher than the world average (Nwachukwu \& Obasi, 2008). This expansive population growth rate has been attributed to some factors with low contraceptive usage contributing a large chunk (Olugbenga-Bello, et.al., 2011). Negative effects and consequences of lack of utilization of family planning by individuals, families, communities and the nation at large result in high maternal morbidity and mortality rate, high infant mortality rate, increase in the trend of child abuse such as battered baby syndrome, child labour, increase in teenage pregnancy, juvenile delinquency, child trafficking, among others. Unfortunately, the society has not been able to take optimal advantage of the family planning services available. It is on this premise that this study investigated methods of family planning used in Olorunda Local Government Area of Osun State, Nigeria over a period of one and a half years.

\section{Methodology}

According to the 2006 population censures, the population of Olorunda Local Government Area of Osun State is 126, 374. The male and female population is $49.4 \%$ and $50.6 \%$ respectively. Olorunda Local Government Area of Osun State had nine maternity centres out of which four were randomly selected for the purpose of this study, namely: Akogun Maternity centre, Oke-Onitea Maternity Centre, Ota-Efun Maternity Centre, and Atelewo Maternity Centre. The population for this study are the clients that came for family planning in these maternity centres between October 2005 and April 2007 within the period under study. Total sampling technique was used to select the study respondents. All available records of 494 clients who attended the clinics within the period under study were studied and analyzed using simple percentages.

\section{Results and discussion}

Research question 1: Will there be difference in the choice of family planning methods used by women of different age groups in Olorunda Local Government Area of Osun State, Nigeria?

Table 1: Difference in the choice of family planning among age groups.

\begin{tabular}{|l|c|}
\hline Age group & Frequency (\%) \\
\hline Less than or equal to 20ys & $9(1.8)$ \\
\hline $21-30$ & $244(49.4)$ \\
\hline $31-40$ & $185(37.4)$ \\
\hline $41-50$ & $31(6.3)$ \\
\hline Age not recorded but appeared as 'adults' & $25(5.1)$ \\
\hline Total & $494(100 \%)$ \\
\hline
\end{tabular}


Table 1 above showed that $1.8 \%$ of women that utilized the family planning are of the ages of 20years downward, $49.4 \%$ are $21-30 y e a r s, 37.4 \%$ are $31-40$ years, while $6.3 \%$ are $41-50$ years. $5.1 \%$ were not recorded. This implies that only few adolescents are making use of the family planning facilities. This could be attributed to the fact that little or no provision is made for this age group. Young people especially the adolescents have been largely left out of family planning resolution. Few countries provide reproductive health and family planning services freely to the youth. This finding is in line with the that of Santhya (2003) which showed that among women who have not given birth, the contraceptive needs of only 25 per cent of women are satisfied which may be partly due to the neglect of young women by the programme that perceives a contraceptive need among young people only after they have completed their family formation. Haberland, McGrory and Santhya (2001) hinted that evidence is emerging, however, that young couples, despite community norms that favour a first child soon after marriage, would prefer delaying the first birth until they have spent more time together to know each other better. Conversely, Olugbenga-Bello, et.al., (2011) in a study of contraceptive practices among women in rural communities in South-Western Nigeria found out that there is no significant association between age, marital status, tribe and educational status and the use of family planning.

Research question 2: Will there be difference in family planning status of women in Olorunda Local Government Area of Osun State, Nigeria?

Table 2: Difference in family planning status of women

\begin{tabular}{|l|l|}
\hline Family planning status & Frequency (\%) \\
\hline New & $237(48.0)$ \\
\hline Revisits & $201(40.7)$ \\
\hline Old & $13(2.6)$ \\
\hline Unclassified status in the record & $43(8.7)$ \\
\hline Total & $494(100 \%)$ \\
\hline
\end{tabular}

Table 2 above showed that $48 \%$ of women who came for family planning within the period of study are new cases. $40.7 \%$ are revisits (i.e. came for follow-up), $40.7 \%$ were revisits, $2.6 \%$ were old cases, while $8.7 \%$ were unclassified. This indicates that more women are taking to family planning which could be attributed to measures like enlightenment campagns, rallies, distribution of handbills, jingles on radio and television, among other programmes aimed at making people aware of family planning methods and its availability. This finding is in line with that of Moronkola, Ojediran and Amosu (2006) which showed that though people were knowledgeable about benefits of family planning, yet, there is the need for continuous education of women about reproductive health issues and integration of men's participation in family planning programme to increase utilization of family planning services

Conversely, the study of Olugbenga-Bello, et.al., (2011) showed that lack of adequate information and ignorance are key factors militating against family planning practice in Nigeria. They further warned that the introduction and acceptance of modern family planning methods is crucial in controlling the population growth as this will prevent 23-million unplanned births, 22-million abortions, 1.4-million infant deaths, 142,000 pregnancy related deaths and 505,000 children losing their mothers due to pregnancy related deaths.

Research question 3: Will there be difference in family planning methods used by women in Olorunda Local Government Area of Osun State, Nigeria?

Table 3: Difference in family planning methods.

\begin{tabular}{|l|l|}
\hline Family planning methods & Frequency $(\%$ \\
\hline Oral & $94(19.0)$ \\
\hline Injectables & $265(53.5)$ \\
\hline IUCDs & $128(25.9)$ \\
\hline Total & $494(100 \%)$ \\
\hline
\end{tabular}

Table 3 above showed that $19 \%$ of women who came for family planning use oral contraceptive pills, $53.5 \%$ uses injectables, $25.9 \%$ uses intra uterine contraceptive device, while $1.6 \%$ uses barrier method. This indicates that larger percentage of the women use injectibles, which could be attributed to its convenience. This finding is in line with that of Subramanian, McGrath, Ndlovu and Gafos (2008) which showed that injectables were the most common contraceptive method among screened women, with $31 \%$ reporting current use as a primary method, condoms (12\%), sterilization (6\%) and pills (4\%) as primary contraceptive methods. Their study further showed that seventy-five women $(9 \%)$ reported concurrent use of condoms and injectables, pill or sterilization. In order to ensure that women who want to utilize contraceptives are able to do so, it is necessary to understand the factors influencing their contraceptive choices. 
Research question 4: Will there be difference in the choice of family planning methods used by women of different parity status in Olorunda Local Government Area of Osun State, Nigeria?

Table 4: Difference in family planning choice by women of different parity status.

\begin{tabular}{|l|l|}
\hline Parity status & Frequency (\%) \\
\hline Nulliparous & $51(10.3)$ \\
\hline Primigravida & $65(13.2)$ \\
\hline Multiparous (2-4 children) & $316(64.0)$ \\
\hline Grand multiparous & $62(12.6)$ \\
\hline Total & $494(100 \%)$ \\
\hline
\end{tabular}

Table 4 above shows that $10.3 \%$ of the women who use one family planning method were nulliparous, $13.2 \%$ were primigravida, $64 \%$ were multiparous. It is clear that multiparous women utilize the family planning services than women of other parity status. This could be as a result of the misconception that family planning is meant for those who do not wish to have children any more. This finding is in line with that of Hidiroglu et al (1999)which showed that some women believe that after using contraceptive, the possibility of a new pregnancy would decrease. Further corroborating this finding is the study of Pathfinder International (2011) which showed that there are many community norms and traditions that continue to have strong influence on community members' acceptance and ability to access reproductive health services. This is sometimes associated with the belief that ovaries would get lazy while using contraceptive. Issues of religious and traditional beliefs still impede total acceptance of child spacing, especially with regard to modern family planning methods.

\section{Conclusion and recommendations}

The use of family planning methods in the maternity centres chosen for this study is fair but there much room for improvement. This study revealed that very few people patronize the maternity centres. Among this few, greater percentage prefers injectables to other family planning methods. It was also discovered that the adolescents do not patronize these health centres. Hence, we recommended that the entire populace should be sensitized on the advantages of family planning methods, while deliberate steps must be taken to disabuse their minds of misconceptions about family planning. Also, midwives should be put through ways of proper completion of client's records, as the study showed some laxity in this regard. Similarly, an expanded reproductive health programme must address men, both in terms of their own health needs and in terms of their shared responsibility as partners, husbands and fathers. The role of male health workers who could play an active role in promoting male involvement needs to be clearly defined.

\section{References}

[1]. Almuam, Y.K.A. 2007. Knowledge, attitude and practice towards modern family planning in Mukalla, Yemen. Thesis submitted in fulfillment of the requirements for the degree of Master of Science (Family Health). Retrieved August $19^{\text {th }}, 2011$ from

[2]. Carl, H. and Mary, M.K. 2008. World Population Data Sheet. Washington D.C: Population Reference Bureau.

[3]. diagnostic report, Baroda," Unpublished.

[4]. Ganatra, B. 2000. Abortion research in India: What we know, and what we need to know in Haberland, N., E. McGrory and K.G. Santhya. 2001. "First time parents project, Supplemental Health Survey, India. Mumbai: IIPS.

[5]. Khurfeld, M. (2006). Thousands feared born in Nigeria's population explosion. The Onion. www.theonion.com

[6]. Marston C, Cleland J. 2004. The effects of contraception on obstetric outcome. Geneva: World Health Organization. Retrieved August $19^{\text {th }}, 2011$ from www.who.int/reproductive health/publications/2004/effects_contraception/text.pdf

[7]. Moronkola OA., Ojediran MM. and Amosun A. (2006). Reproductive Health Knowledge, beliefs and determinants of contraceptives use among women attending family planning clinics in Ibadan, Nigeria. Africa Health Science; 6(3): $155-159$.

[8]. National Commission on Population. 2002. Report of the Working Group on Strategies to Address Unmet Needs. New Delhi: National Commission on Population.

[9]. Nwachukwu I. and Obasi O.O. (2008). Use of Modern Birth Control Methods Among Rural Communities in Imo State, Nigeria. African Journal of Reproductive Health. 12(1): 101-108.

[10]. Olugbenga-Bello, A.I., Abodunrin, O.L. and Adeomi, A.A. 2011. Contraceptive Practices Among Women in Rural Communities in South-Western Nigeria. Retrieved December 5 ${ }^{\text {th }}, 2011$ from http://www.globaljournals.org/GJMR_Volume11/

[11]. Osemwenkha, S.O. 2004. Gender Issue in contraceptive use among educated woman in Edo State, Nigeria. African Health Sciences, 4(1): 40-49.

[12]. Pathfinder International. 2011. Reproductive health knowledge and practices in northern Nigeria: Challenging misconceptions. The Reproductive Health/Family Planning Service Delivery Project in Northern Nigeria. Retrieved December $8^{\text {th }}$, 2011 from http://www.pathfind.org.

[13]. Population Reference Bureau. (2002) Demographic Profile: Women of the World. Washington, D.C. Publications, $331-382$.

[14]. Santhya, K.G. 2003. Changing family planning scenario in India: An overview of recent evidence. Population Council, New Delhi, India. Retrieved August 15 $5^{\text {th }}, 2011$ from http://www.popcouncil.org/pdfs/wp/seasial/seawp17.pdf

[15]. Sedgh G, Henshaw H, Singh S, Ahman E, Shah IH. 2007. Induced abortion: estimated rates and trends worldwide. Lancet 370:133845 .

[16]. Subramanian, L., McGrath, N., Ndlovu, H. \& Gafos, M. 2008. Family planning methods among women in a vaginal microbicide feasibility study in rural KwaZulu-Natal, South Africa. African Journal of Reproductive Health, 12(2): 45-63. Retrieved 9 September, 2013 from www.ajol /index.php/ajrh/article/view/7858 
[17]. United Nations Millennium Project. 2006. Public choices, private decisions: sexual and Millennium Development Goals. New York: U.N. Millennium Project.

[18]. United Nations Population Fund. 2007. Myths, misrepresentation and fear. Addressing condom use barriers. Occasional Publication.

[19]. United Nations Population Fund. 2005. Reproductive health fact sheet. (accessed June 11, 2008), Available from: www.unfpa.org/swp/2005/presskit/factsheets/facts rh.htm/

[20]. United Nations. 1995. Report of the International Conference on Population and Development, Cairo, 5-13 September 1994. New York.

[21]. Visaria, L. 2000. From contraceptive targets to informed choice: The Indian experience, in Women's Reproductive Health in India, (ed) by Ramasubban, R. and Jejeebhoy, S.J., New Delhi: Rawat Publications, pp. 186-235. 